\title{
Originals
}

\section{Effect of Gestational Diabetes on Insulin Receptors in Human Placenta}

\author{
S. Durán-García, J. Gomez Nieto, and A. Marañon Cabello \\ Department of Internal Medicine ( $2^{\mathrm{a}}$ Cátedra de Patología Médica), University Hospital, Valladolid, Spain
}

Summary. The aim of this work was the characterization of insulin binding to a partially purified preparation of plasma membranes from gestational diabetic placenta in order to establish a comparison with normal pregnancy. A decrease in the number of insulin receptors per $\mathrm{mg}$ protein in placenta from gestational diabetic mothers was found. Comparable inhibitory effects of unlabelled insulin suggest that the binding affinities were similar in both groups of patients. The ability of the placental preparation to degrade ${ }^{125} \mathrm{I}$ insulin was not significantly different in both situations. The existence of a negative feed-back regulation of the insulin receptors in placental membranes was suggested by the fact that plasma insulin levels were significantly higher in the gestational diabetic mothers.

Key words: Normal pregnancy, gestational diabetes, insulin receptors, plasma membranes, placenta, insulin levels.

Tissue insulin resistance in obesity and maturityonset diabetes has been shown to be associated with a decrease in number of insulin receptors on plasma membranes [1-3]. The placenta is a readily available source of human insulin receptors [4-6] and thus offers a convenient model for the study of insulin receptor binding in normal pregnancy, and in the situation of carbohydrate intolerance associated with gestation. Although little is known of the factors regulating placental function, it appears that the placenta is an active site of insulin metabolism [7].

In previous studies Posner [5] failed to show a modification of the number and/or affinity of insulin receptors in diabetic pregnancy. However, Harrison et al. [8] showed that the specific binding of insulin to a microsomal-membrane fraction from human placentas, obtained from insulin-dependent diabetic mothers, was significantly decreased when compared with placentas from normal women.

The aim of the present work was to study whether insulin receptor interaction in placentas from gestational diabetic mothers is normal, using a partially purified preparation of placental plasma membranes.

\section{Material and Methods}

\section{Materials \\ Purified porcine "monocomponent" insulin (lot S 835158, 27 I.U./mg) was purchased from Novo Research Institute (Copenha- gen, Denmark) and was used both for iodination and as unlabelled standard in the binding studies. Carrier-free $\mathrm{Na}^{125} \mathrm{I}(300 \mathrm{mCi} / \mathrm{ml}$, in $\mathrm{NaOH}$ solution, $\mathrm{pH} 8-11$, less than $1 \%$ of ${ }^{126}$ ) was purchased from the Radiochemical Centre (Amersham, England). DEAE- cellulose (microgranular DE 52) was from Whatman and bovine serum albumin (BSA, fraction V) from Sigma Chem. Co. Other chemicals were of reagent grade.}

\section{Patients}

An oral $100 \mathrm{~g}$ glucose load was given to 50 antenatal women after ten hours of fasting. All glucose tolerance tests were performed between 28 and 32 weeks of gestation. Each woman had been instructed to ingest a diet containing at least $250 \mathrm{~g}$ carbohydrates for the three days preceding the test. Blood samples were drawn at hourly intervals during a 3-hour period. From those mothers in whom the test clearly suggested gestational diabetes, we used for the present study only the placentas from those (ten patients) who were also available for the glucose tolerance test carried out two months after delivery. Placentas from an equal number of normal women were used as controls. The diagnosis of gestational diabetes was made on the basis of their glucose tolerance (defined according to the criteria described by O'Sullivan and Mahan, 9), and the existence of obstetric pathology (abortion, macrosomic infants at birth) in previous pregnancies. None of the selected 
Table 1. Comparison of specific binding of ${ }^{125}$ I-insulin and $5^{\prime}-$ nucleotidase activities in different tissue fractions from normal placentas

\begin{tabular}{lcc}
\hline Tissue fraction & $\begin{array}{l}5^{\prime} \text {-nucleotidase } \\
\text { nmol Pi/min/mg prot. }\end{array}$ & $\begin{array}{l}{ }^{125} \text { I-insulin bound } \\
\text { fmol/mg }\end{array}$ \\
\hline Homogenate & $65 \pm 6$ & $3 \pm 1$ \\
$50,000 \mathrm{~g}$ & $122 \pm 25$ & $20 \pm 3$ \\
$\mathrm{~F}_{1}$ fraction & $731 \pm 44$ & $50 \pm 4$ \\
$\mathrm{~F}_{2}$ fraction & $158 \pm 8$ & $10 \pm 2$ \\
\hline
\end{tabular}

The tissue fractions were prepared by homogenization and differential centrifugation as described in Material and Methods. Studies of ${ }^{125} \mathrm{I}$-insulin binding $(0.16 \mathrm{nmol} / \mathrm{l})$ were performed at $24^{\circ} \mathrm{C}$ during a sixty minute incubation period. Each value is the mean \pm SEM of ten experiments with ten different placental fractionations

women, whether gestational diabetic or normal, were receiving drugs which might affect the glucose tolerance test, nor were they obese before onset of pregnancy. The weight gain during pregnancy was between 8.5 and $10.5 \mathrm{~kg}$ and there was no difference between the two groups.

\section{Placental Tissue and Tissue Fractionation}

Human full-term placentas, obtained after vaginal delivery, were processed according to the method described by Posner [5], with the following modifications: the homogenization was performed in ten volumes of sucrose $(0.3 \mathrm{~mol} / \mathrm{l})$ in a glass homogenizer with a motor-driven teflon pestle. The homogenate was filtered through two and then four layers of cheesecloth. After centrifugation for fifteen minutes at $600 \mathrm{~g}$, the supernatant was centrifuged again at $50,000 \mathrm{~g}$ for sixty minutes to obtain the microsomal-membrane pellet. This pellet was suspended by gentle homogenization in 0.1

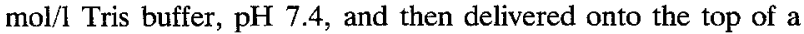
centrifuge tube containing a $30 \%$ to $60 \%$ (wt/wt) linear sucrose gradient. It was then centrifuged again at $100,000 \mathrm{~g}$ for sixty minutes. After this centrifugation we recognized three different layers: the first $\left(\mathrm{F}_{1}\right)$, intermediate $\left(\mathrm{F}_{2}\right)$ and last $\left(\mathrm{F}_{3}\right)$ layers appeared at sucrose densities of $30 \%, 38-40 \%$ and $50 \%$, respectively. These three layers were characterized by electron microscopic examinations, by their $5^{\prime}$-nucleotidase activities and by their ability to bind ${ }^{125} \mathrm{I}$-insulin. They were resuspended and

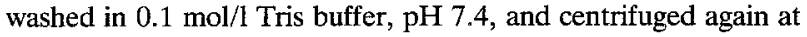
$50,000 \mathrm{~g}$ for ten minutes in a Sorvall (RC5-B) centrifuge, and then frozen at $-80^{\circ} \mathrm{C}$ until assay. All the above procedures were carried out at $4^{\circ} \mathrm{C}$.

\section{Monoiodination of Insulin}

Insulin was iodinated directly with $0.8-1.0 \mathrm{I}$ atom per molecule (specific activity $300-380 \mu \mathrm{Ci} / \mu \mathrm{g}$ or $1,800-2,280 \mathrm{Ci} / \mathrm{mmol}$ ) using the chloramine $\mathrm{T}$ method [10]. Iodinated products were chromatographed on DEAE-cellulose [11], except that urea was omitted because of the small quantity of polypeptide applied to the ion exchanger.

\section{Binding Studies}

Studies of binding of ${ }^{125} \mathrm{I}$-insulin to the different placental fractions were conducted at the temperatures and for the time intervals indicated in the legends to the figures and tables. Incubations were carried out in a final volume of $0.4 \mathrm{ml} \mathrm{Krebs} \mathrm{Ringer} \mathrm{Phosphate}$ buffer, $\mathrm{pH} 7.5$, containing ${ }^{125} \mathrm{I}$-insulin at $0.03-0.20 \mathrm{nmol} / \mathrm{l}$, unlabelled insulin at various concentrations from 0 to $17 \mu \mathrm{mol} / 1$, placental proteins at $0.30-0.40 \mathrm{mg} / \mathrm{ml}$ and BSA at $10.0 \mathrm{mg} / \mathrm{ml}$. At the times indicated, duplicate $150 \mu \mathrm{l}$-aliquot samples from each incubation tube were transferred to microfuge tubes (Beckman) and membrane-bound ${ }^{125} \mathrm{I}$-insulin was isolated by a ten minute centrifugation at $50,000 \mathrm{~g}$ in a Sorvall centrifuge. Except when stated otherwise, data are reported as specific binding: this is obtained by substracting from the total binding the amount of labelled insulin which is not displaced by a great excess $(17 \mu \mathrm{mol} / 1)$ of unlabelled insulin.

\section{Other Analytical Studies}

The degree of insulin degradation was measured following the procedures previously described [12], using rat liver plasma membranes prepared according to the Neville method [13]. Maternal plasma insulin was measured by radioimmunoassay with the use of ${ }^{125}$ I-human insulin and a guinea-pig anti-human insulin serum [14]: the results were expressed in terms of a human insulin standard (lot 12569 MC. 25.7 I.U./mg) purchased from Novo Research Institute. Blood glucose was measured with a glucose-oxidase kit (God-perid method, Boehringer Mannheim). Protein was measured by the Lowry procedure [15] and 5 -nucleotidase assays were carried out at $37^{\circ} \mathrm{C}[16]$ and with a trichloroacetic acid deproteinization step before addition of the molybdate reagent [17].

\section{Characterization of Placental Preparations}

Table 1 shows the specific binding of ${ }^{125}$ I-insulin and 5 '-nucleotidase activity in each tissue fraction obtained during the purification of normal placenta. The 5 '-nucleotidase activity was much greater in the $100,000 \mathbf{F}_{1}$ fraction than in the others. Specific binding of ${ }^{125}$ I-insulin paralleled 5 -nucleotidase activity and was significantly higher in $F_{1}$ fraction. Partially purified plasma membranes $\left(\mathrm{F}_{1}\right.$ fraction) were used in all subsequent studies. The 5 '-nucleotidase activities in plasma membranes obtained from normal and gestational diabetic placenta were not significantly different: values were (means $\pm \mathrm{SEM} ; \mathrm{n}=10) 731 \pm 44$ and $765 \pm 50 \mathrm{nmol} \mathrm{Pi} /$ $\mathrm{min} / \mathrm{mg}$ protein, respectively. ${ }^{125} \mathrm{I}$-insulin specifically bound to purified plasma membranes obtained from normal and gestational diabetic placenta was linearly related to the protein concentrations, at least between 100 and $1,000 \mu \mathrm{g} / \mathrm{ml}$. This range includes the concentrations employed in the binding experiments and permits normalization of the data on the basis of protein concentration.

In order to exclude the possibility that the insulin binding studies might be influenced by the presence of blood elements in the placenta we performed the following control experiment: one normal placenta was extensively perfused using cold saline via the two umbilical arteries and the placental cotyledons used for the homogenization were also thoroughly washed. The insulin binding capacity of the placental plasma membranes prepared after this perfusion procedure was not significantly different from that found in plasma membranes prepared without placental perfusion.

Electron microscopic examinations showed that the plasma membrane fraction consisted of vesicles of various shapes and sizes which showed a triple-layered structure at high magnification (data not shown).

\section{Calculations}

Mean values, the SEM, and Student's t-test were all calculated as outlined by Snedecor [18]. Unless stated otherwise, data are given as means \pm SEM. 
Table 2. Glycaemic and insulinaemic values in normal and gestational diabetic mothers before delivery. In the latter group the glucose load was repeated two months after delivery

\begin{tabular}{|c|c|c|c|c|c|c|}
\hline \multirow[t]{2}{*}{ Time } & \multicolumn{3}{|c|}{ Glucose, $\mathrm{mg} / 100 \mathrm{ml}$} & \multicolumn{3}{|c|}{ Insulin, $\mu \mathrm{U} / \mathrm{ml}$} \\
\hline & $\begin{array}{l}\text { Normal } \\
n=10\end{array}$ & $\begin{array}{l}\text { G. D. before } \\
\mathrm{n}=10\end{array}$ & $\begin{array}{l}\text { G. D. after } \\
n=10\end{array}$ & $\begin{array}{l}\text { Normal } \\
\mathrm{n}=10\end{array}$ & $\begin{array}{l}\text { G. D. before } \\
\mathrm{n}=10\end{array}$ & $\begin{array}{l}\text { G. D. after } \\
\mathbf{n}=10\end{array}$ \\
\hline $0 \mathrm{~min}$. & $76 \pm 2$ & $100 \pm 9^{b}$ & $82 \pm 2^{c}$ & $10 \pm 2$ & $17 \pm 2^{a}$ & $10 \pm 2^{c}$ \\
\hline $60 \mathrm{~min}$. & $114 \pm 6$ & $203 \pm 9^{b}$ & $139 \pm 15^{\mathrm{d}}$ & $73 \pm 7$ & $112 \pm 15^{a}$ & $59 \pm 9^{d}$ \\
\hline $120 \mathrm{~min}$. & $94 \pm 3$ & $187 \pm 6^{b}$ & $108 \pm 19^{d}$ & $60 \pm 5$ & $128 \pm 13^{b}$ & $45 \pm 10^{d}$ \\
\hline $180 \mathrm{~min}$. & $78 \pm 2$ & $172 \pm 9^{\mathrm{b}}$ & $84 \pm 10^{\mathrm{d}}$ & $36 \pm 3$ & $93 \pm 13^{\mathrm{b}}$ & $31 \pm 8^{d}$ \\
\hline
\end{tabular}

${ }^{\mathrm{a}} \mathrm{p}<0.05$ vs normal; ${ }^{\mathrm{b}} \mathrm{p}<0.01$ vs normal; ${ }^{\mathrm{c}} \mathrm{p}<0.05$ vs gestational diabetics (G. D.) before; $\mathrm{d}<\mathrm{p} 0.01$ vs G. D. before. Values are means \pm SEM

\section{Results}

\section{Glucose Tolerance and Insulin Levels}

Table 2 shows the glucose and insulin profiles of the gestational diabetic patients, as well as those of normal women of the same gestation stage. None of these women had ever been treated with insulin. Gestational diabetic mothers were significantly hyperinsulinaemic, both in the basal state and during the oral glucose tolerance test. In our gestational diabetic patients the glucose and insulin profiles returned spontaneously to the normal range two months after delivery.

\section{Studies of Insulin Binding. Time Course}

Under identical experimental conditions and throughout the entire time course, plasma membranes from placentas of the gestational diabetic mothers bound only $45-50 \%$ as much insulin as did membranes from normal mothers (Figure 1). At $24^{\circ} \mathrm{C}$ steady-state was attained by 30 to 120 minutes. All subsequent binding studies were conducted at the steady-state of binding at $24^{\circ} \mathrm{C}$ after sixty minutes incubation period. The differences in the specific binding of ${ }^{125} \mathrm{I}$-insulin observed between the two types of plasma membranes could not be attributed to differences in non-specific binding: in both cases the latter represents $5-10 \%$ of total ${ }^{125}$ I-insulin bound to plasma membranes.

The degradation of ${ }^{125}$ I-insulin by the plasma membranes from normal and gestational diabetic placentas was also studied. ${ }^{125} \mathrm{I}$-insulin at $0.16 \mathrm{nmol} / 1$ was incubated with $0.2-0.6 \mathrm{mg}$ protein $/ \mathrm{ml}$ at $24^{\circ} \mathrm{C}$ during a sixty minute period. After centrifugation the radioactivity remaining in the supernatant was tested for its ability to bind to fresh rat liver membranes. The percentage of ${ }^{125} \mathrm{I}$-insulin degraded was $14 \pm 5$ and $15 \pm 3$ (means $\pm S E M ; n=3$ ) for normal and gestational diabetic placental plasma membranes, respectively.

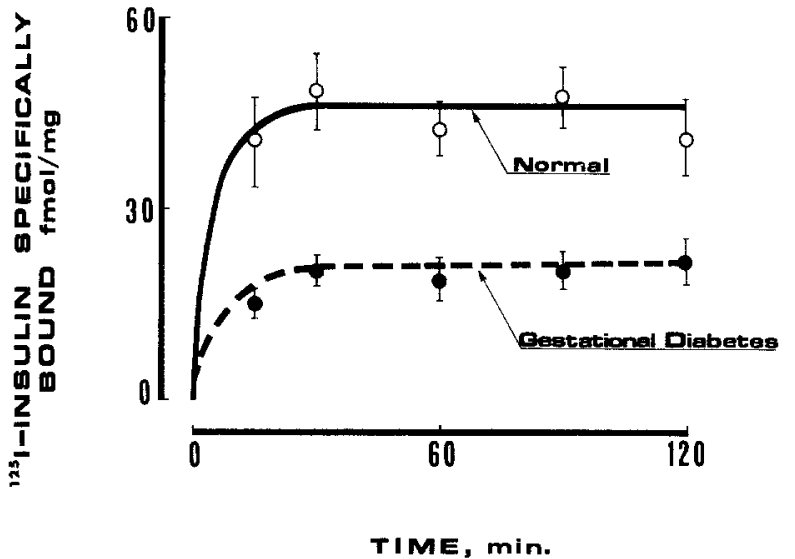

Fig. 1. Time course of binding of ${ }^{125} \mathrm{I}$-insulin to purified placental plasma membranes from normal pregnant women and gestational diabetic patients. Insulin at $0.16 \mathrm{nmol} / \mathrm{l}$ was incubated with $0.2-0.6 \mathrm{mg}$ protein $/ \mathrm{ml}$ for the times indicated at $24^{\circ} \mathrm{C}$, in the absence and in the presence of unlabelled insulin at $17 \mu \mathrm{mol} / \mathrm{l}$. The latter was used to determine the nonspecific binding which has been subtracted from each experimental point. Each point is the mean $\pm S E M$ of ten experiments with different placental preparations

\section{Insulin Binding at Steady-State}

Unlabelled insulin at physiological concentrations inhibited the binding of ${ }^{125}$ I-insulin to a similar extent for both normal and gestational diabetic placenta (Figure 2). With $0.8 \mathrm{nmol} / 1(5 \mathrm{ng} / \mathrm{ml}$ or $125 \mu \mathrm{U} / \mathrm{ml})$ a $20 \%$ inhibition was observed. Fifty per cent inhibition of ${ }^{125} \mathrm{I}$-insulin binding was obtained with insulin at $3.2 \mathrm{nmol} / 1(20 \mathrm{ng} / \mathrm{ml}$ or $500 \mu \mathrm{U} / \mathrm{ml})$. Scatchard analysis (not shown) indicated that the specific binding fits a curvilinear model. The apparent affinity constant for the "high" affinity site was similar for the normal and gestational diabetic placenta $(1 \times$ $10^{9} \mathrm{~mol} / \mathrm{1}^{-1}$ ).

Over a wide range of insulin concentrations from $0.1 \mathrm{nmol} / 1(0.6 \mathrm{ng} / \mathrm{ml}$ or $15 \mu \mathrm{U} / \mathrm{ml})$ to saturating ones of $17.5 \mathrm{nmol} / 1(100 \mathrm{ng} / \mathrm{ml}$ or $2,500 \mu \mathrm{U} / \mathrm{ml})$ the 


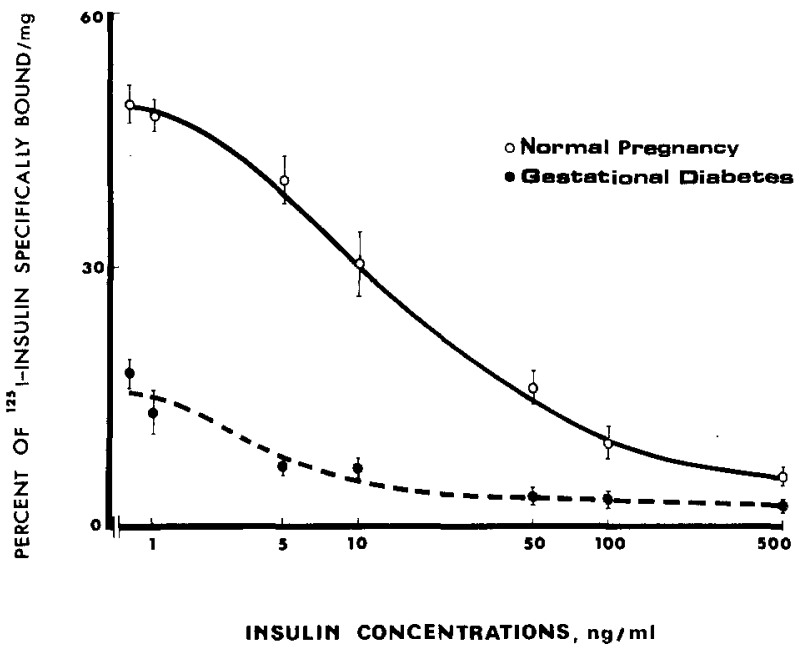

Fig. 2. Effect of unlabelled insulin on the binding of ${ }^{125} \mathrm{I}$-insulin in the plasma membrane fraction from normal and gestational diabetic placenta. Within simultaneous experiments ${ }^{125} \mathrm{I}$-insulin at $0.16 \mathrm{nmol} / 1$ was incubated with plasma membrane fraction of normal placenta $(0.20-0.40 \mathrm{mg}$ protein $/ \mathrm{ml})$ and of the gestational diabetic placenta $(0.40-0.60 \mathrm{mg}$ protein $/ \mathrm{ml})$ for sixty minutes at $24^{\circ} \mathrm{C}$. The data, expressed as the percentage of total ${ }^{125} \mathrm{I}$-insulin bound, are plotted as a function of the concentration of unlabelled insulin; they have been normalized to binding to $1 \mathrm{mg}$ protein $/ \mathrm{ml}$. The nonspecific binding has been subtracted. Each point is the mean \pm SEM of five repeated experiments carried out with five different membrane preparations; in each experiment determinations were done in duplicate

[ INSULIN] $n g / m$ I

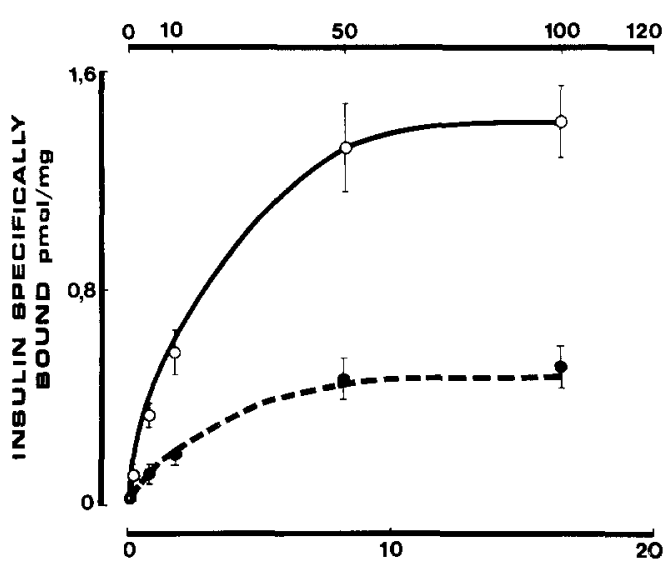

[ INSULIN] $n$ mol/I

Fig. 3. In five separate experiments, carried out with five different membrane preparations, the binding of insulin was simultaneously measured in purified plasma membranes from normal (white circles) and gestational diabetic placentas (black circles), after sixty minutes incubation at $24^{\circ} \mathrm{C}$. The nonspecific binding has been subtracted from the total binding and amounts of hormone specifically bound are plotted as a function of total insulin concentration. Each point is the mean \pm SEM of five separate experiments plasma membranes from gestational diabetic placentas bound only $25-30 \%$ as much insulin as those from normal ones (Figure 3). At each insulin concentration, the amount of insulin bound was three to fourfold lower for gestational diabetic than for normal placenta. Thus it appears that a decrease in the number of binding sites is the main factor leading to the decreased insulin binding.

\section{Discussion}

The regulation of insulin receptors in the placenta when carbohydrate intolerance was present in the mother has been previously investigated $[5,8]$. The number of insulin receptors was decreased in a microsomal-membrane preparation from placentas of insulin-dependent diabetic mothers [8]. However, this point has not been studied extensively in untreated gestational diabetic mothers, though three of the seven patients studied by Posner [5] might be included in this group. Harrison et al. [8] indicated that in diet-treated gestational diabetic mothers the insulin binding to microsomal-membrane placental fractions was not significantly different from that found in normal placenta.

The present work characterizes the insulin binding to purified placental plasma membranes from normal and untreated gestational diabetic mothers, and shows a decrease in the number of insulin receptors in the latter situation. Comparable inhibitory effects of unlabelled insulin on specific ${ }^{125}$ I-insulin binding suggest that the binding affinity constants were similar in both groups of patients. Harrison et al. [8] have previously shown that the decreased insulin binding capacity of the placenta from insulindependent diabetic mothers could not be attributed to a receptor occupation by insulin. Other hormones such as human placental lactogen did not compete with the ${ }^{125}$ I-insulin binding to its receptors in placenta [6]. Moreover, human placental lactogen was not significantly increased in the plasma from gestational diabetic patients [19].

In agreement with a previous report [20], maternal plasma insulin was found to be significantly increased in our gestational diabetic patients. Different investigations carried out both "in vitro" [21] and "in vivo" [22-23] show that insulin modulates the concentration of its specific receptors in the target cells (down regulation). The present findings confirm these observations, since the placenta from gestational diabetic mothers was exposed to high concentrations of maternal plasma insulin.

Fetal hyperinsulinism is thought to be responsible for the large placenta [24] and large infants [25] born 
of insulin-dependent diabetic mothers, but in our study the placental weight in gestational diabetic mothers was not significantly different as compared to normal pregnancy. The metabolic significance and/or the pathophysiological implications of this reduced number of insulin receptors in the placenta from untreated gestational diabetic mothers are not clear at present. If data obtained in the present investigation and those reported by Harrison et al. [8] may be compared, in spite of the differences in the placental preparations used, it would appear that diettreatment of the gestational diabetic mothers might prevent this reduction in the number of placental insulin receptors.

Acknowledgements. We are indebted to Drs $\mathbf{J}$. Navarro Clemente (Dept. Obstetrics \& Gynaecology) and C. Belmonte \& A. Sillero (Dept. Physiology) for their contribution and to Ms. F. Bagot and A. Perez for the skilled technical assistance. This work was supported by the "Comisión Asesora de Investigación Científica y Técnica" grant n 1931/1976.

\section{References}

1. Olefsky, J. M., Reaven, G. M.: Decreased insulin binding to lymphocytes from diabetic subjects. J. Clin. Invest. 54, 1323-1328 (1974)

2. Archer, J. A., Gorden, P., Roth, J.: Defect in insulin binding to receptors in obese man. J. Clin. Invest. 55, 166-174 (1975)

3. Bar, R. S., Gorden, P., Roth, J., Kahn, C. R., De Meyts, P.: Fluctuations in the affinity and concentration of insulin receptors on circulating monocytes of obese patients. Effects of starvation, refeeding and dieting. J. Clin. Invest. 59, 1123-1135 (1976)

4. Haour, F., Bertrand, J.: Insulin receptors in the plasma membrane of human placenta. J. Clin. Endocrinol. Metab. 38, 334-337 (1974)

5. Posner, B. I.: Insulin receptors in human and animal placental tissue. Diabetes 23, 209-218 (1974)

6. Marsall, R. N., Underwood, L. E., Voina, S. J., Foushee, D. B., Van Wyk, J. J.: Characterization of the insulin and somatomedin-C receptors in human placental cell membranes. J. Clin. Endocrinol. Metab. 39, 283-292 (1974)

7. Posner, B. I.: Insulin metabolizing enzyme activities in human placental tissue. Diabetes 22, 552-560 (1973)

8. Harrison, L. C., Billington, T., Clark, S., Nichols, R., East, I., Martin, F. I. R.: Decreased binding of insulin by receptors on placental membranes from diabetic mothers. J. Clin. Endocrinol. Metab. 44, 206-209 (1977)

9. O'Sullivan, J. B., Mahan, C. M.: Criteria for the oral glucose tolerance test in pregnancy. Diabetes 13, 278-285 (1964)

10. Greenwood, F. C., Hunter, W. H., Vlover, J. S.: The preparation of ${ }^{131}$ I-labelled human growth hormone of high specific radioactivity. Biochem. J. 89, 114-123 (1963)
11. Freychet, P., Roth, J., Neville, D. M. Jr.: Monoiodoinsulin: demonstration of its biological activity and binding to fat cells and liver membranes. Biochem. Biophys. Res. Commun. 43, 400-408 (1971)

12. Freychet, P., Kahn, C. R., Roth, J., Neville, D. M. Jr.: Insulin interaction with liver plasma membranes: independence of binding of the hormone and its degradation. J. Biol. Chem. 247, 3953-3961 (1972)

13. Neville, D. M., Jr.: Isolation of an organ specific protein antigen from cell surface membrane of rat liver. Biochim. Biophys. Acta 154, 540-552 (1968)

14. Rosselin, G., Assan, R., Yalow, R. S., Berson, S. A.: Separation of antibody-bound and unbound peptide hormones labelled with iodine-131 by talcum powder and precipitated silica. Nature 212, 355-357 (1966)

15. Lowry, O. H., Rosebrough, N. J., Farr, A. L., Randall, R. J.: Protein measurement with the Folin phenol reagent. J. Biol. Chem. 193, 265-275 (1951)

16. Widnell, C. C., Unkeless, J. C.: Partial purification of a lipoprotein with $5^{\prime}$-nucleotidase activity from membranes of rat liver cells. Proc. Natl. Acad. Sci. USA 61, 1050-1057 (1968)

17. Kahn, C. R., Neville, D.M. Jr., Roth, J.: Insulin-receptor interactions in the obese hyperglycemic mouse. A model of insulin resistance. J. Biol. Chem. 248, 244-250 (1973)

18. Snedecor, G. W.: Statistical Methods, 5th edition. Iowa: Iowa State University Press 1956

19. Spellacy, W. N., Buhi, W. C., Birk, S. A., McGreary, S. A.: Distribution of human placental lactogen in the last half of normal and complicated pregnancies. Am. J. Obstet. Gynecol. 120, 214-233 (1974)

20. Kuhl, C.: Serum proinsulin in normal and gestational diabetic pregnancy. Diabetologia 12, 295-300 (1976)

21. Gavin, J. R., III, Roth, J., Neville, D. M. Jr., De Meyts, P., Buell, D. N.: Insulin-dependent regulation of insulin-receptor concentrations: a direct demonstration in cell culture. Proc. Natl. Acad. Sci. USA 71, 84-88 (1974)

22. Goldfine, I. D., Kahn, C. R., Neville, D. M. Jr., Roth, J., Garrison, M., Bates, R. W.: Decreased binding of insulin to its receptors in rats with hormone induced insulin resistance. Biochem. Biophys. Res. Commun. 53, 852-857 (1973)

23. Archer, J. A., Gorden, P., Gavin, J. R., III, Lesniak, M. A., Roth, J.: Insulin receptors in human circulating lymphocytes. Application to the study of insulin resistance in man. J. Clin. Endocrinol. Metab. 36, 627-633 (1973)

24. Lister, U.M.: The ultrastructure of the placenta in abnormal pregnancy. J. Obstet. Gynaecol. Br. Commonw. 72, 203-214 (1965)

25. Horger, E. O., III, Miller, M. C., III, Conner, E. D.: Relation of large birth weight to maternal diabetes mellitus. Obstet. Gynecol. 45, 150-154 (1975)

Received: March 30, 1978,

and in revised form: August 22, 1978

Dr. Santiago Durán-García

Department of Internal Medicine

University Hospital

Valladolid

Spain 